\title{
A Review and Synthesis of the Economic Value- Added Literature
}

by

Andrew C. Worthington ${ }^{\text {由 }}$

School of Economics and Finance

Queensland University of Technology

Tracey West

School of Accounting, Banking and Finance

Griffith University

\begin{abstract}
:
With increasing pressure on firms to deliver shareholder value, there has been a renewed emphasis on devising measures of corporate financial performance and incentive compensation plans that encourage managers to increase shareholder wealth. One professedly recent innovation in the field of internal and external performance measurement is a trade-marked variant of residual income known as economic value-added $\left(E V A^{\circledR}\right)$. This paper attempts to provide a synoptic survey of EVA's conceptual underpinnings and the comparatively few empirical analyses of value-added performance measures. Special attention is given to the GAAP-related accounting adjustments involved in EVA-type calculations.
\end{abstract}

\section{Introduction}

An accepted financial axiom is that the role of managers is to maximise the wealth of shareholders by the efficient allocation of resources. In order to operationalise this objective, shareholder wealth is traditionally proxied by either standard accounting

\footnotetext{
${ }^{\dagger}$ The authors would like to thank participants at the $12^{\text {th }}$ Annual Australasian Finance and Banking Conference, University of New South Wales for helpful comments on an earlier version of this paper. The financial support of a Queensland University of Technology Faculty of Business Research Initiative Grant (RIG) is also gratefully acknowledged.

‡ Corresponding author: Dr. A.C. Worthington, School of Economics and Finance, Queensland University of Technology, GPO Box 2434, Brisbane QLD, 4001. Tel. (07) 3864 2658; Fax. 07) 3864 1500; email. a.worthington@qut.edu.au
} 
magnitudes (such as profits, earnings and cash flows from operations) or financial statement ratios (including earnings per share and the returns on assets, investment and equity). This financial statement information is then used by managers, shareholders and other interested parties to assess current firm performance, and is also used by these same stakeholders to predict future performance. Further, under the semi-strong form of the efficient market hypothesis, the publicly available information contained in these variables is readily interpreted by the market, and thereby incorporated into future stock prices.

Unfortunately, the empirical literature to date suggests that there is no single accounting-based measure upon which one can rely to explain changes in shareholder wealth (Chen and Dodd, 1997; Riahi-Belkaoui, 1993; Rogerson, 1997; Lehn and Makhija, 1997). This is despite the fact that such a measure would prove invaluable to the various parties interested in aspects of firm performance. Lee (1996, 32), for example, argues that the search for a superior measure of firm valuation is a, if not the, key feature of contemporary empirical finance:

For years, investors and corporate managers have been seeking a timely and reliable measurement of shareholders' wealth. With such a measure, investors could spot over- or underpriced stocks, lenders could gauge the security of their loans and managers could monitor the profitability of their factories, divisions and firms.

One professedly recent innovation in the field of internal and external performance measurement is a trade-marked variant of residual income (net operating profits less a charge for the opportunity cost of invested capital) known as economic valueadded $\left(E V A^{\circledR}\right)$. As a starting point its developer and principal advocate, US-based business consultants Stern Stewart and Co. (hereafter referred to as Stern Stewart) (Stewart, 1991, 66), argue that:

[E]arnings, earnings per share, and earnings growth are misleading measures of corporate performance [and that] the best practical periodic performance measure is economic value-added. [EVA] is the financial performance measure that comes closer than any other to capturing the true economic profit of an enterprise. EVA also is the performance measure most directly linked to the creation of shareholder wealth over time.

Citing in-house research, Stewart $(1994,75)$ further suggests that "EVA stands well out from the crowd as the single best measure of wealth creation on a 
contemporaneous basis [and] is almost $50 \%$ better than its closest accounting-based competitor [including EPS, ROE and ROI] in explaining changes in shareholder wealth". Using these findings, Stern Stewart has built a significant presence in the highly-competitive value-based performance consulting market with "literally hundreds of firms adopting EVA to some degree, among them Coca-Cola Co., Eli Lilly and Co., and the Postal Service in the US" (Biddle et al. 1998).

EVA $^{\circledR}$ figures have also been heavily promoted in the UK, Australia, Canada, Brazil, Germany, Mexico, Turkey and France, amongst others (Stern Stewart, 1999), used to provide published rankings of managerial performance (Ferguson, 1997), and several international companies have adopted $E V A^{\circledR}$ for performance measurement and/or incentive compensation packages. For example, in Australia the ANZ Banking Group, Fletcher Challenge Limited, James Hardie Industries and the Wrightson Group, have implemented $E V A^{\circledR}$ financial management systems in recent years (Rennie, 1997).

Support for $E V A^{\circledR}$ has also been forthcoming from other sources. Fortune has called it "today's hottest financial idea", "The Real Key to Creating Wealth" (30 September 1993) and "A New Way to Find Bargains" (9 December 1996) [and has printed EVA ${ }^{\circledR}$ performance rankings since 1993], and Peter Drucker (1995) in the Harvard Business Review suggests that EVA's growing popularity reflects, amongst other things, the demands of the information age for a measure of 'total factor productivity' (Stern, Stewart and Chew, 1995, 86). Finally, there has been widespread adoption of $\mathrm{EVA}^{\circledR}$ by security analysts since "instead of using a dividend discount approach, these models measure value from the point of the firms' capacity for ongoing wealth creation rather than simply wealth distribution" (Herzberg, 1998, 45) (emphasis added). The purpose of the present paper is to review the theoretical underpinnings of $E V A^{\circledR}$, and to reconcile the often-competing claims as to its empirical superiority over other accounting-based measures of firm performance.

The remainder of the paper is sub-divided into five main areas. The second section outlines the concept of EVA ${ }^{\circledR}$ and other value-based performance metrics. The third section discusses the calculation of EVA ${ }^{\circledR}$. The accounting adjustments involved in these $E V A^{\circledR}$ calculations and their implications are discussed in the fourth section. 
The fifth section reviews the extant empirical literature within a common framework. The final section contains some brief concluding remarks.

\section{The Concept of Economic Value-Added}

Despite the relatively recent adoption of $E V A^{\circledR}$ as an internal and external financial performance measure, its conceptual underpinnings derive from a well-established microeconomic literature regarding the link between firm earnings and wealth creation (Bell, 1998). For much of this history, at least since Alfred Marshall's Principles of Economics, the focus of analysis has been on adjustments to accounting earnings to reflect the opportunity cost of capital, primarily because the unadjusted measure can be a misleading indicator of performance in both theory and practice.

In a seminal contribution, Marshall (1920) concluded, "the gross earnings of management which a man is getting can only be found after making up a careful account of the true profits of his business, and deducting interest on his capital". Later, the desirability of quantifying 'economic profit' as a measure of wealth creation was operationalised by David Solomon (1965) "as the difference between two quantities, net earnings and the cost of capital". This measure of 'residual income' is then defined in terms of after-tax operating profits less a charge for invested capital which reflects the firm's weighted average cost of capital. Close parallels are thereby found in the related (non-trademarked) concepts of 'abnormal earnings', 'excess earnings', 'excess income', 'excess realisable profits' and 'super profits' (Biddle et al., 1997). As Peter Drucker put it in his Harvard Business Review (1995) article:

EVA is based upon something we have known for a long time: What we call profits, the money left to service equity, is usually not profit at all. Until a business returns a profit that is greater than its cost of capital, it operates at a loss. Never mind that it pays taxes as if it had a genuine profit. The enterprise still returns less to the economy than it devours in resources... Until then it does not create wealth; it destroys it.

Just as $E V A^{\circledR}$ bears a close semblance to non-trademarked financial performance measures, it is also closely related to performance metrics offered by other consultants. For example, the Chicago-based Boston Consulting Group, Price Waterhouse and HOLT Value Associates employ variations of Cash Flow Return on 
Investment or CFROI. CFROI is typically calculated in two steps. First, the inflationadjusted cash flows available to all capital owners in the firm are measured and compared with the inflation-adjusted gross investment made by the capital owners. Second, the gross cash flow to gross investment is translated into an internal rate of return by adjusting for the finite economic life of depreciating assets and the residual value of non-depreciating assets (such as land and working capital).

In addition, there are many other value-based metrics that are even more closely related to $E V A^{\circledR}$. In fact, the legal conflict between Stern Stewart's EVA ${ }^{\circledR}$ and KPMG's 'Economic Value Management' over the proprietary nature of EVA ${ }^{\circledR}$ suggests even closer, less discernible differences in these products (Lieber 1998). Myers (1996), amongst others, has arrived at this conclusion: "The fact is, EVA, CFROI, and all the others are premised on fundamental economics that 20 years ago was called residual income". It is this perception of EVA ${ }^{\circledR}$ as "a practical and highly flexible refinement of the economists' concept of 'residual income' - the value that is left over after a company's stockholders (and all other providers of capital) have been adequately compensated" that provides the basis for the following discussion (Stern, Stewart and Chew, 1995, p. 32).

\section{Calculation of EVA and Related Accounting-Based Measures}

Economic value-added $\left(E V A^{\circledR}\right)$ is an accounting-based measure of operating performance. It thereby has close parallels with two sets of alternative performance measures. The first set consists of closely related, value-based measures and includes, most notably, the Stern Stewart measure of Market Value-Added or MVA ${ }^{\circledR}$. Stern Stewart calculates MVA “... by adding the capital taken in by a company during its lifetime through securities offerings, loans, and retained earnings, [making] some EVA-like adjustments (such as capitalising and amortising R\&D expenditures), and subtract[ting] the total from the current value of the company's stock and debt" (Meyers 1996: 46).

The main distinguishing feature of $\mathrm{MVA}^{\circledR}$ is that it is largely a cumulative measure and therefore communicates the market's present verdicts on the net present value (NPV) of all the firms' past, current and contemplated capital investment projects (O’Byrne 1996: 199). However, in contrast to $M V A^{\circledR}, E V A^{\circledR}$ is a measure that focuses 
on firm performance over a specific period. It therefore has a similar time perspective to a second set of constituent measures of firm performance; namely, earnings before extraordinary items $(E B E I)$, net cash flow from operations $(N C F)$ and residual income $(R)$.

Starting with $E B E I$ as the most basic indicator of firm value we have:

$$
\mathrm{EBEI}=\mathrm{NCF}+\mathrm{ACC}
$$

where $E B E I$ is the sum of net cash flow from operations (NCF) and accruals $(A C C)$. $A C C$ is defined as total accruals relating to operating activities and is composed of depreciation, amortisation, changes in non-cash current assets, changes in current liabilities, and changes in the non-current portion of deferred taxes.

Net operating profit after tax (NOPAT) is a closely related indicator of current and future firm performance and is calculated by adding after-tax interest expense (ATI) to $E B E I(1)$ :

$$
\mathrm{NOPAT}=\mathrm{EBEI}+\mathrm{ATI}=\mathrm{NCF}+\mathrm{ACC}+\mathrm{ATI}
$$

As indicated, the most significant difference between EBEI (1) and NOPAT (2) is that the later separates operating activities from financing activities by including the aftertax effect of debt financing (interest expense). As a measure of operating profit, no allowance is therefore made in (2) for the financing activities (both debt and equity) of the firm. One measure that does is residual income $(R I)$ where operating performance is reduced by a net charge for the cost of all debt and equity capital employed:

$$
\mathrm{RI}=\mathrm{NOPAT}-(\mathrm{WACC} \times \mathrm{CAP})=\mathrm{NCF}+\mathrm{ACC}+\mathrm{ATI}-\mathrm{CC}
$$

where WACC is an estimate of the firm's weighted average cost of capital, and capital $(C A P)$ is defined as assets (net of depreciation) invested in going-concern operating activities, or equivalently, contributed and retained debt and equity capital, at the beginning of the period. The product of the firm's WACC and the amount of contributed capital thereby forms a capital charge $(C C)$ against which NOPAT is reduced to reflect the return required by the providers of debt and equity capital. $A$ positive (negative) $R I$ indicates profits in surplus (deficit) of that required by the 
suppliers of debt and equity capital and is associated with an increase (decrease) in shareholder wealth.

The primary point of departure for EVA from $R I(3)$ is the adjusting of both NOPAT and CAP for purported 'distortions' in the accounting model of performance. EVAtype adjustments are made to both accounting measures of operating profits (NOPAT), and accounting measures of capital (CAP). EVA ${ }^{\circledR}$ thereby reflects adjustments to GAAP in terms of both operating and financing activities. Simplifying, EVA is thus determined by:

$$
\mathrm{EVA}=\mathrm{NCF}+\mathrm{ACC}+\mathrm{ATI}-\mathrm{CC}+\mathrm{ADJ}
$$

where the total $E V A$ accounting adjustment $(A D \mathcal{J})$ is the net figure of adjustments to NOPAT $(N C F+A C C+A T I)$ less the adjustment to capital in determining $C C$ $(W A C C \times C A P)$.

\section{EVA and the Role of Accounting Adjustments}

The calculation of EVA ${ }^{\circledR}$ itself therefore consists of two separate but related steps. The primary adjustment is where a capital charge is subtracted from net operating profit after-tax (NOPAT). The capital charge is derived from multiplying the firm's overall financing cost, as reflected in the weighted average cost of capital (WACC), by the amount of invested capital. Invested capital in turn is defined as total assets, net of non-interest bearing current liabilities. In this form, EVA ${ }^{\circledR}$ is essentially the same as residual income, though the latter measure is normally expressed as net income less a charge for the cost of equity capital (with the cost of debt already included in the calculation of net income) (Young, 1999).

The second and more controversial step consists of a series of adjustments to GAAP-based numbers. Consisting of some 120 to 150 possible adjustments, these changes are made on the basis of both empirical and theoretical concerns. First, it is argued that adjustments to accounting numbers are required in order "...to achieve higher correlations between the short term measure (in this case EVA), and share prices, which in turn can lead to more congruent goals for divisional managers and shareholders as well as a more reliable indicator of corporate performance for security analysts and portfolio managers (Young, 1999, p. 8). 
Second, at its root is the argument that not only are accounting earnings an inappropriate proxy for value creation, but that managers who are evaluated and compensated on the basis of earnings "...may take actions that increase earnings but destroy value, or fail to take actions that may reduce earnings but create value" (Young, 1999, p. 8). Young (1999, p. 8) summarises the process as follows:

These adjustments aim to 1) produce an EVA figure that is closer to cash flows, and therefore less subject to the distortions of accrual accounting; 2) remove the arbitrary distinction between investments in tangible assets, which are capitalised, and intangible assets, which tend to written off as incurred; 3) prevent the amortisation, or write-off, of goodwill; 4) eliminate the use of successful efforts accounting; 5 ) bring off-balance sheet debt into the balance sheets; and 6) correct biases caused by accounting depreciation.

Notwithstanding the large number off adjustments that are possible, companies adopting Stern Stewart's EVA ${ }^{\circledR}$ Financial Management System (as distinct from the publicly available performance rankings) generally make no more than fifteen adjustments to published accounts, though Young (1999) observes that this figure has progressively fallen in recent years. Young $(1999,9)$ attributes at least some of this decline to the reticence of corporate executives to diverge from GAAP-based numbers and the realisation "...that most of the proposed adjustments have little or no qualitative impact on profits".

In terms of Young's (1999) critique, the following is noted. First, the issues relating to the costliness of deviations from GAAP have been well documented in the EVA ${ }^{\circledR}$ literature. For example, Zimmerman (1997) argues that such deviations significantly increases both litigation costs (with the implication that the official financial statements are not really 'true and fair') and administrative costs (through accounting systems becoming more complicated, costly to administer, and difficult for operating managers to comprehend). Second, the requirement for $E V A^{\circledR}$ adjustments to have a impact on profits would accord with Stewart's (1991) recommendation that adjustments should be limited to those situations where the outcomes are significant, where the item of interest may be reasonably influenced by management, and where the required information is readily available.

The remaining modifications to a company's conventional accounts may be meaningfully grouped as adjustments to capital balances, and adjustments to 
earnings. Included under these classifications are recognising non-recurring gains and losses, research and development, deferred taxes, intangibles, depreciation, provisions for warranties and bad debts, restructuring changes, and macroeconomic conditions (Rennie, 1997).

Firstly, 'successful efforts' accounting means that only the costs of successful investments (those with future economic significance) are capitalised and placed on the balance sheet. Unsuccessful investments are conventionally written off. For example, in the oil industry it is usual for many exploration holes to be drilled before one with viable quantities of oil is found. EVA ${ }^{\circledR}$ proponents say that the unsuccessful investments are just as important to shareholders as successful investments. Hence, the investment in all holes drilled should go on the balance sheet and the loss will be recognised gradually in future periods in the form of higher capital charges, and thus lower $E V A^{\circledR}$. Thus the adjustment is to obtain the present value of all additional capital in future periods. This is equal to the amount of the write-off (Stewart, 1994, 79). Recognising non-recurring gains and losses in this way is argued to keep the "invested capital in the balance sheet and is thus a constant reminder to management of its obligations to earn sufficient returns on all capital resources. It also takes away management's ability to time the recognition of losses, and is thus an immensely powerful tool for the analyst" (Young, 1999, 10).

Secondly, research and development (R\&D) is treated by Stern and Stewart in a similar fashion. Under conventional GAAP, R\&D costs are expensed. But as $R \& D$ is an investment, $E V A^{\circledR}$ advocates propose its capitalisation. The argument here is that in a company which does not capitalise R\&D, managers might be tempted to underinvest because short-term profits will be adversely affected by R\&D expenditures whereas the benefits will not be realised until future periods (Young, 1999, 11). To capitalise $R \& D$, the adjustment is to add back R\&D costs to NOPAT and shareholders' equity. The capitalised costs are then written off gradually, with an amortisation period based on the number of future periods expected to benefit from whatever products or services are developed from the R\&D (Young, 1999, 10). When comparing a firm that capitalises $R \& D$ against one that follows conventional accounting, it is noticed that once a steady state is reached, operating income is not affected by the R\&D adjustment. However, the $E V A^{\circledR}$ figure is lower in the firm that 
capitalised R\&D, and this more accurately reflects the higher capital charges. However, adjustments such as this may be of no real benefit if management has qualitative targets to achieve, rather than a financial objective (Young, 1999, 18).

Thirdly, taxes are only charged to profits as they are paid, rather than when they arise from timing differences between taxable income and book income under GAAP. The most significant source of the latter is the accelerated treatment of depreciation for tax purposes as against book income, with the argument that timing differences will recognise more book income than tax income (a deferred tax liability). Alternatively, deferred tax assets arise when provisions are made for future costs that serve to reduce current book income. These may include provisions for warranties, restructuring and environmental clean-up. The net change of EVA ${ }^{\circledR}$ is to add (or subtract) these changes in deferred tax to more accurately reflect the actual cash flows to tax authorities. In other words, the "deferred tax adjustment brings EVA closer to cash flows, and thus eliminates any influence on profits from one of the most important components of accrual accounting" (Young, 1999, 12). Most proponents argue that this focus on cash flows is the most useful component of EVA $^{\circledR}$ calculations [see, for example, McClenahan (1998), Kimball (1998), Jackson (1996), Uyemura, Kantor, Petit (1996) and Zimmerman (1997)]. However, Young $(1999,6)$ argues that this is a major limitation since deferred tax has been shown to be one component of earnings which is consistently value-relevant. Accordingly, this adjustment effectively reduces the value-relevance of EVA ${ }^{\circledR}$.

Fourthly, intangibles (especially goodwill arising from corporate acquisitions) are not automatically written off in an EVA ${ }^{\circledR}$ system. The argument is that the write-off of goodwill (whether at acquisition or more gradually through capitalisation and amortisation) effectively removes at least part of the acquirer's investment in the target from the balance sheet, "...thereby lessening management's burden to earn a competitive return on that portion of invested capital" (Young, 1999, 12). The adjustment is to reverse any amortisation of goodwill that has already taken place and restore it to invested capital. The counter-argument is that whatever the treatment of goodwill, the "present value of charges to the future results from the acquisition of goodwill will be the same" (Young, 1999, 17). Thus there may be no obvious need for this adjustment. 
Fifth, the adjustment made to depreciation considers that while a fast write-down of plant is preferred for tax purposes, the purported reality is "...that the operational value of plant does not fall as quickly as depreciation schedules suggest and management performance should reflect this" (Joel Stewart as quoted in Rennie, 1997). Also, straight-line accounting depreciation means that rates of return tend to be understate the true internal rates of return in the early years and overstate it in later years (Stewart, 1994, 80). This gives an illusion of improving performance, when in fact the only reason EVA ${ }^{\circledR}$ would increase is because of the depreciation method used (Young, 1999, 14). EVA ${ }^{\circledR}$ proponents argue that EVA ${ }^{\circledR}$ should be constant over the life of the asset, and should be depreciated in exactly the same way that bank loans are amortised (Young, 1999, 14). This adjustment is mostly ignored in corporate enterprise and at the analyst level because, unless the company is in a high growth phase, depreciation figures under the annuity method are likely to be close to those under the straight-line method (Young, 1999, 18).

Sixth, restructuring changes that involve cash payments are considered capital under $E V A^{\circledR}$. The argument is that such adjustments should only be made to generate returns in a later period, and therefore should also provide an appropriate return. Finally, adjustments are also made for 'extractive industries' (mining, forestry, oil and gas). It is posited that broad changes in these industries result from the overly heavy emphasis on exogenous commodity prices: conditions over which management has little or no discretionary control.

Although only a few adjustments are discussed, the process that Stern Stewart's $E_{V A}{ }^{\circledR}$ calculations employ has obvious intuitive appeal. Nevertheless, Young (1999) argues that many of these adjustments are of little importance at the company level, and some may be difficult, if not impossible, to replicate at the security analyst level. Further, in the corporate environment the adjustments may be costly and not easily understood. Chen and Dodd (1997, 331), for example, argue that a firm could “...implement performance measures based on [the computationally simpler] residual income which will likely provide them with most of the practical benefits promised by an EVA system'. Also because of the current disclosure regulations, financial analysts may find calculating GAAP prohibitive, subjective, and it may also reduce the ability to accurately compare the performance of corporations. One last limitation 
of EVA is that is still based on accounting figures, irrespective of the GAAP-related adjustments.

\section{Empirical Evidence on Measures of EVA}

Within the voluminous market efficiency literature, a large number of studies have investigated the relationship between accounting numbers and stock returns. Such work is useful since if a high correlation exists between accounting-based information and market returns, then the variable under consideration would provide an accurate indication of the firm's value, and therefore increasing firm value or identifying market under-pricings could be made solely on that basis. Traditionally, most studies have focused on accounting profits, earnings and accruals, but more recently cash flows and residual income have attracted attention. A number of additional variables have also been investigated within this construct, including capital expenditure, company profits and losses, and research and development expenditure. It is within this broad literature that all empirical studies of EVA ${ }^{\circledR}$ and other value-added information have been positioned.

The overall finding of the value-relevance literature is that any number of accountingbased information sources can potentially influence share prices. The empirical literature, however, also suggests that earnings generally dominates most other measures in explaining stock returns, although the more recent literature indicates that earnings should not be relied upon, largely because of its discretionary nature. Research into the information content of other variables, especially cash flows, has increased because of the apparent limitations in earnings figures, and because of the increased demand for investors and analysts to correctly identify firm values.

While accounting profit measures such as earnings per share, return on equity, return on assets and return on investment are among the most commonly used performance measures, they are often criticised for not taking into consideration the total cost of capital and for being unduly influenced by accrual-based accounting conventions. In contrast, EVA ${ }^{\circledR}$, the difference between after-tax operating profits and the total cost of capital, is promoted as a measure of a company's real profitability. Since value is a primary concern to investors, proponents claim that EVA ${ }^{\circledR}$ is the only performance measure that ties directly to a stock's intrinsic value (Stewart, 1991). It 
has also been generally asserted that stock prices and EVA show a remarkable tendency to move up and down together. EVA ${ }^{\circledR}$ proponents insist on the superior information given by the EVA ${ }^{\circledR}$ figure when compared to normal accounting figures. This has been empirically tested by Biddle, Bowen and Wallace (1997) Chen and Dodd (1997), Lehn and Makhija (1997), Rogerson (1997) and Bao and Bao (1996; 1998), among others. At least some studies included in this literature have also focused on closely related concepts, such as residual income [see, for example, Dechow et al. (1999)]. Both strands of this empirical literature are equally deserving of attention.

Generally there are mixed results supporting the usefulness of value-added variables (including $\mathrm{EVA}^{\circledR}$ ). To start with, Bao and Bao (1998) investigated the usefulness of value-added and abnormal economic earnings of 166 US firms. The results indicated that value added is a significant explanatory factor in market returns, and its explanatory power is higher than that of earnings. Riahi-Belkaoui (1993) also examined the relative and incremental content of value-added, earnings and cash flows in the US context. The results indicated that the information content of valueadded is a major determinant of market returns, providing incremental information content beyond both net income and cash flow. Later, Riahi-Belkaoui and Fekrat (1994) also found that performance measures based on net value-added had lower variability and higher persistency than many corresponding accounting-based numbers, including earnings and cash flows.

In a closely related study, Riahi-Belkaoui and Picur (1994) confirmed the association between both relative changes in earnings and net value-added and the relative change in security prices. They also found that both the levels of net value-added and the changes in net value-added play a role in security valuation. Riahi-Belkaoui (1996) also compared the use of linear and non-linear models in specifying the relationship between value-added and market returns. He found that models relating accounting and market returns have more explanatory power when, firstly, the accounting returns are expressed by the relative changes in net value-added, and secondly, the relation is a nonlinear convex-concave function (Riahi-Belkaoui, 1996). The possibility of nonlinearity more-broadly defined accounting relationships has also 
been investigated by Freeman and Tse (1992), Cheng et al (1992), Das and Lev (1994), and Lipe et al (1998).

There have also been a number of studies concerned with the predictive ability of value-added data. Karpik and Riahi-Belkaoui (1994) used the market model test value-added variables in explaining market risk, and found that the incremental information content given by value-added variables is beyond that provided by accrual earnings and cash flows. Earlier work by Bannister and Riahi-Belkaoui (1991) also used the market model to explain a target firm's abnormal returns during the takeover period. Their findings suggested that takeover targets have lower valueadded ratios than other firms in their industries in the year preceding completion of the takeover.

One key feature of the implementation of Stern Stewart's EVA ${ }^{\circledR}$ system comprises a revised managerial compensation plan and an amended internal benchmark for corporate performance. There have been a number of studies that have also addressed this aspect of value-relevance. Lehn and Makhija (1997) enter the debate by questioning which performance measure does the best job of predicting the turnover of chief executive officers (CEOs). Their results suggested that labour markets evaluate CEOs on the basis of EVA ${ }^{\circledR}$ and MVA ${ }^{\circledR}$ performances, rather than on the basis of more conventional accounting measures. From a slightly different perspective, Rogerson (1997) investigated the moral hazard that exists with managers to increase shareholder wealth and to thereby increase the firm's cash flows so as to increase managerial compensation. They concluded that residual income (or $E V A^{\circledR}$ ) as a performance measure will ensure that managers will always make efficient investment decisions.

Wallace (1996) also tested the ability of residual income plans to align managers actions with increasing shareholder wealth. He did this by selecting a sample of firms that began using a residual income performance measure in their compensation plans, and comparing their performance to a control sample of firms that continued to use traditional earnings-based incentives (Wallace, 1996). Wallace (1996) concluded that management actions after the adoption of the residual income compensation plan were consistent with the strong rate of return discipline associated with the explicit capital charge. Wallace (1996) also found weak evidence suggesting that 
capital market participants generally responded favourably to the adoption of residual income-based compensation plans.

The wider issue of ownership structure and value-added performance has also received some attention in the evolving literature. Pavlik and Riahi-Belkaoui (1994) examined this relationship, and found that there is a significant non-monotonic relationship between value-added performance and ownership structure. RiahiBelkaoui (1996) expanded on this and examined performance plan adoption and ownership structure. He found that, following performance plan adoption, profitability will increase in 'owner-controlled' firms, but not in 'manager-controlled' firms. Askren et al (1994) also examined performance plan adoption, and found that firms adopting accounting-based performance plans did not experience any greater gains in accounting returns or productivity than do a set of control firms.

Finally, Robertson and Batsakis (1999) empirically examined the role an organisation's characteristics may play in determining the emphasis on executive share options within the compensation system. It was found that '....share options are viewed from an organisational perspective to be an effective behavioural control mechanism' (Robertson and Batsakis, 1999, 25). The importance of the executive compensation plan is that it maximises shareholder wealth, thereby achieving high EVAs. As it has also been shown that investors respond favourably to the adoption of the plan, perhaps a flow-over effect in years to come will be that they recognise increases $E^{\circledR}{ }^{\circledR}$ to be favourable instead of traditional accounting-based performance measures.

The aforementioned studies have been used to suggest that EVA ${ }^{\circledR}$ is generally superior to earnings and other accounting-based performance measures in explaining security returns. However, there is also evidence to suggest that EVA ${ }^{\circledR}$ is not a superior measure of firm performance. Biddle, Bowen and Wallace (1997), for example, question whether EVA ${ }^{\circledR}$ is more highly associated with stock returns and firm values than accrual earnings, and evaluated which components of EVA ${ }^{\circledR}$, if any, contribute to these associations. The results of their study of 773 large US firms indicated that earnings is more highly associated with market-adjusted annual returns than either residual income $(\mathrm{RI})$ or $E V A^{\circledR}$, and that all three of these measures 
dominate cash flows from operations (CFO). Thus, when considering the relative and incremental information content results together, neither EVA ${ }^{\circledR}$ nor RI appears to dominate earnings in its association with stock market returns.

Riahi-Belkaoui (1996) likewise tested the informational content of net value-added components disclosed concurrently with earnings. He found that the earnings component of value-added is viewed favourable by the market, while the nonearnings component (interest, tax and wages) is negatively related to market return. Similarly, Chen and Dodd (1997) reported that not a single EVA ${ }^{\circledR}$ measure (average EVA per share, change of standardised $E V A^{\circledR}$, return on capital, capital growth and return on capital minus the cost of capital) is able to account for more than 26 percent of the variation in stock returns. Collectively the regression model containing the five $E V A^{\circledR}$ variables explained only some 41.5 percent of the variation in stock returns. They concluded that although $E V A^{\circledR}$ measures provide relatively more information than the traditional measures of accounting profit (including earnings per share, return on assets and return on equity) in terms of the strength of their associations with stock return, traditional accounting measures still have more significant information content. They also found that $E V A^{\circledR}$ and residual income variables are highly correlated and are almost identical in terms of association to stock return.

The apparent inability of $E V A^{\circledR}$ to explain at least as much variation in stock returns as conventional earnings has been taken up by De Villiers (1997) and Burlett and Hedley (1997), amongst others. For example, De Villiers (1997) suggested that a major disadvantage of $E V A^{\circledR}$ is that it is based on accounting profits, that a discrepancy exists between accounting profit and 'true' profit, and that this disaggregation is exacerbated by inflation. DeVilliers $(1997,293)$ argued that under conditions of inflation $E V A^{\circledR}$ cannot be used to estimate actual productivity, and called for an 'adjusted EVA (AEVA) procedure'. AEVA is calculated by firstly restating the capital base in current values, then determining the asset structure of the firm, and finally calculating the required accounting return. The final step is to multiply the required accounting return by the current value of capital, and subtracting this figure from net operating profit after tax (NOPAT). DeVillers (1997) also suggested that 
AEVA has applications outside of orthodox performance analysis, especially as an alternative to inflation accounting and when estimating profitability under inflation.

Biddle (1998) has also suggested several reasons why EVA ${ }^{\circledR}$ performs relatively poorly in comparison with earnings in explaining stock returns. The first reason is that $E A^{\circledR}$ may not outperform the current realisations of other performance measures, such as earnings, in proxying for future equity, as against debt and equity, cash flows. Secondly, Stern Stewart's estimates of the charge for capital and accounting adjustments may contain measurement error relative to what the market is using to value firms. Further, most studies use Stern Stewart's publicly available database, which may not include many custom adjustments that are made for specific clients.

Third, changes in the components unique to $\mathrm{EVA}^{\circledR}$ (cost of capital, amount of capital) may be slow changing and already impounded into security prices in a short window. Thus there is no 'surprise' exhibited by the market. Nevertheless, some studies even over longer time periods do not lend support to $E V A^{\circledR}$. Fourth, the types of data needed to compute $E V A^{\circledR}$ are not easily estimated, and the market does not have this information during the sample period. Fifth, adjustments made by Stern Stewart may remove accruals that market participants use to infer the firm's future prospects, thus reducing the information content provided by EVA ${ }^{\circledR}$. Finally, Biddle (1998) suggests that the market itself may be inefficient, and thereby failing to recognise the 'benefits' of $E V A^{\circledR}$. This would be consistent with the notion of an 'earnings myopia'.

\section{Concluding Remarks}

When examining existing theoretical and empirical research in this area, a number of salient points emerge. First, despite the relatively recent adoption of $E A^{\circledR}$ as an internal and external financial performance measure, its conceptual underpinnings derive from a well-established microeconomic literature regarding the link between firm earnings and wealth creation. And apart from the GAAP-related adjustments incorporated in EVA-type calculations, the measure itself is almost identical to the non-proprietary measure of residual income.

Second, the GAAP-related adjustments themselves accordingly comprise the most unique and contentious aspect of EVA ${ }^{\circledR}$. While these adjustments are argued to 
produce earnings figures that are closer to cash flows and correct, amongst other things, for purported 'biases' in the treatment of intangible assets and depreciation, they are often criticised for having little importance, being difficult to understand, and costly. Paradoxically, the removal of some accruals through these adjustments is argued to reduce, rather than increase, the information content of $E V A^{\circledR}$.

Third, the empirical evidence concerning EVA ${ }^{\circledR}$ has been mixed. Biddle et al. (1997) used relative and incremental information tests to examine whether stock returns were more highly associated with $E V A^{\circledR}$, residual income or cash flow from operations. Biddle et al. (1997, 333) concluded that while "for some firms EVA may be an effective tool for internal decision making, performance measurement, and incentive compensation, it does not dominate earnings in its association with stock market returns". Chen and Dodd (1997) likewise examined different dimensions of the $E A^{\circledR}$ system and concluded: “... not a single EVA measure [annualised EVA return, average EVA per share, change in standardised EVA and average return on capital] was able to account for more than 26 percent of the variation in stock return". Lehn and Makhija (1997) Rogerson (1997) and Biddle, Bowen and Wallace (1997) reached similar conclusions. Lastly, Clinton and Chen (1998) compared share prices and returns to residual cash flow, economic value-added and other traditional measures, and recommended that companies using EVA ${ }^{\circledR}$ consider residual cash flow as an alternative.

However, Bao and Bao (1998, p. 262) in an analysis of price levels and firm valuations concluded that the "results are not consistent for earnings and abnormal economic earnings, but are consistent for value added, i.e., value added is significant in both levels and changes deflated by price analyses". Similarly, Uyemura, Kantor and Petit (1996) demonstrated that EVA ${ }^{\circledR}$ has a high correlation with market value added (the difference between the firm's value and cumulative investor capital) and thereby stock price, while O'Byrne (1996) estimated that changes in EVA ${ }^{\circledR}$ explain more variation in long-term stock returns than changes in earnings. Finally, and from a stock selection perspective, Herzberg $(1998,52)$ concluded that the residual income valuation model (including $E V A^{\circledR}$ ) "appears to have been very effective in uncovering firms whose stock is underpriced when considered in conjunction with expectations for strong earnings and growth". Nevertheless, the bulk of empirical 
evidence indicates that the superiority of $E V A^{\circledR}$ vis-à-vis earnings (as variously defined) has not been forthcoming.

These limitations in the existing literature all suggest future directions for research. To start with, notwithstanding that $\mathrm{EVA}^{\circledR}$ figures are readily available and promoted in the UK, Australia, Canada, Brazil, Germany, Mexico, Turkey and France, no empirical studies of this type (as far as the authors are aware) have been conducted outside the United States. There is an obvious requirement to examine the usefulness of $E V A^{\circledR}$ vis-à-vis traditional financial statement measures in an alternative institutional milieu. A second direction is to follow Biddle's et al. (1997, 303) suggestion that "an avenue for future research suggested by the findings of this study is to examine more closely which components of $E V A^{\circledR}$ and earnings contribute to, or subtract from, information content”. Put differently, given that $E V A^{\circledR}$ consists of nearly 160 potential changes to accounting figures grouped across adjustments to accounting measures of operating profits and capital, there is the requirement to quantify the contribution of these sub-components to overall firm performance.

A final suggestion is to rectify the empirical limitations that appear to dominate this field. Accounting research, for example, frequently uses $R^{2}$ to measure value relevance. Recent evidence suggests that these measures may be confounded by the presence of scale effects in levels regressions (Brown, Lo and Lys, 1999). Likewise, there is the possibility of nonlinearity in these accounting-type relationships [see, for instance, Freeman and Tse (1992), Cheng et al (1992), Das and Lev (1994), and Lipe et al (1998)] and this may also have served to distort research findings in this area. Lastly, most research in this area has tended to concentrate on either cross-sectional data or panel data with a relatively small number of time series. Examination of $E V A^{\circledR}$ over a longer time frame would allow greater empirical certainty on its status as a corporate performance measure.

\section{References}

Askren, B.J., J.W. Bannister and E.L. Pavlik, 1994, The Impact of Performance Plan Adoption on Value Added and Earnings, Managerial Finance 20(9), 27-43.

Bannister, J.W. and A. Riahi-Belkaoui, 1991, Value Added and Corporate Control in the U.S., Journal of International Financial Management and Accounting 3(3), 241-257.

Bao, B-H, and D-H Bao, 1996, The Time Series Behaviour and Predictive Ability Results of Annual Value Added Data, Journal of Business Finance and Accounting 23(3), April, 449-460. 
Bao, B-H, and D-H Bao, 1998, Usefulness of Value Added and Abnormal Economic Earnings: An Empirical Examination, Journal of Business Finance and Accounting 25(1-2), January/March, 251265.

Bell, L.W.W., 1998, Economic Profit: An Old Concept Gains New Significance, Journal of Business Strategy 19(5), September/October, 13-15.

Biddle, G.C., 1998, Economic Value Added: Some Empirical EVAdence, Managerial Finance 24(11), 60-70.

Biddle, G.C., G.S. Bowen and J.S. Wallace, 1997, Does EVA beat Earnings? Evidence on Associations with Stock Returns and Firm Values, Journal of Accounting and Economics 24(3), 301-336.

Brown, S., K. Lo and T. Lys, 1999, Use of $\mathrm{R}^{2}$ in Accounting Research: Measuring Changes in Value Relevance over the Last Four Decades, Journal of Accounting and Economics, 28(1), 83-115.

Chen, S. and J.L. Dodd, 1997, Economic Value Added (EVA): An Empirical Examination of a New Corporate Performance Measure, Journal of Managerial Issues 9 (3), Fall, 318-333.

Cheng, C.S., W. Hopwood, and J.C. McKeown, 1992, Non-Linearity and Specification Problems in Unexpected Earnings Response Regression Model, The Accounting Review 67(3), July, 579-598.

Das, S., and B. Lev, 1994, Nonlinearity in the Returns-Earnings Relation: Tests of Alternative Specifications and Explanations, Contemporary Accounting Research 11(1), 353-379.

De Villiers, J., 1997, The Distortions in Economic Value Added (EVA) Caused by Inflation, Journal of Economics and Business 49, 285-300.

Dechow, P.M., A.P. Hutton and R.G. Sloan, 1999, An Empirical Assessment of the Residual Income Valuation Model, Journal of Accounting and Economics 26, 1-34.

Evraert, S., 1998, Usefulness of Value Added Reporting: A Review and Synthesis of the Literature, Managerial Finance 24(11), 1-15.

Ferguson, A., 1997, Australia's Best Value in Chief Executives, Business Review Weekly, November 24, 57-61.

Ferguson, R., and D. Leistikow, 1998, Search for the Best Financial Performance Measure: Basics are Better, Financial Analysts Journal, January/February, 81-85.

Freeman, R.N., and S.y. Tse, 1992, A Nonlinear Model of Security Price Responses to Unexpected Earnings, Journal of Accounting Research 30(2), Autumn, 185-209.

Herzberg, M.M., 1998, Implementing EBO/EVA Analysis in Stock Selection, Journal of Investing, Spring, 45-53.

Jackson, A., 1996, The How and Why of EVA at CS First Boston, Journal of Applied Corporate Finance 9 (1), Spring, 98-115.

Jackson, S., 1997, Getting to Know EVA, The Australian, August 14, 23.

Karpik, P. and A. Riahi-Belkaoui, 1994, The Effect of the Implementation of the Multidivisional Structure on Shareholder's Wealth: The Contingency of Diversification Strategy, Journal of Business and Accounting 21(3), April, 349-365.

Kimball, R.C., 1998, Economic Profit and Performance Measurement in Banking, New England Economic Review, July/August, 35-53.

Lee, C., 1996, Measuring Wealth, The CPA Magazine, April, 32-37.

Leiber, R.B., 1998, Stern Stewart and KPMG Go To War, Fortune, February 2, 30.

Lipe, R.C., L. Bryant and S.K. Widener, 1998, Do Nonlinearity, Firm-Specific Coefficients, and Losses Represent Distinct Factors in the Relation Between Stock Returns and accounting Earnings? Journal of Accounting and Economics 25, 195-214.

Marshall, A., 1920, Principles of Economics, Porcupine Press, 8th Edition, Macmillan: London, 1990 Reprint, 495-522.

McClenahen, J.S., 1998, Accounting for Change, Industry Week 247 (17), September 21st, 63-65. 
Myers, R., 1996, The Metric Wars, The Magazine for Chief Financial Officers (CFO), October, 18.

O'Byrne, S.F., 1996, EVA and Market Value, Journal of Applied Corporate Finance 9 (1), Spring, 116125.

Pavlik, E., and A. Riahi-Belkaour, 1994, The Effects of Ownership Structure on Value Added-Based Performance, Managerial Finance 20(9), 16-24.

Rennie, P., 1997, Finding the Best, and Worst, Wealth Creators, Business Review Weekly, August 11, 26-27.

Riahi-Belkaeoui, A., 1993, The Information Content of Value added, Earnings, and Cash Flow: US Evidence, The International Journal of Accounting 28, 140-146.

Riahi-Belkaoui, A., 1996, Earnings-Returns Relation Versus Net-Value Added-Returns Relation: A Case for Nonlinear Specification, Advances in Quantitative Analysis of Finance and Accounting 4, 175-185.

Riahi-Belkaoui, A., and M.A. Fekrat, 1994, The Magic in Value Added: Merits of Derived Accounting Indicator Numbers, Managerial Finance 20(9), 3-15.

Riahi-Belkaoui, A. and R.D. Picur, 1994, Explaining Market Returns: Earnings Versus Value Added Data, Managerial Finance 20(9), 44-55.

Riahi-Belkaoui, A. and R.D. Picur, 1994, Net Value Added as An Explanatory Variable for Returns, Managerial Finance 20(9), 56-64.

Rogerson, W.P., 1997, Intertemporal Cost Allocation and Managerial Investment Incentives: A Theory Explaining the Use of Economic Value Added as a Performance Measure, Journal of the Political Economy 105 (4), 770-795.

Solomons, D., 1965, Divisional Performance: Measurement and Control, Homewood, IL: Richard D. Irwin.

Stern Stewart, 1999, Internet site <http:/www.sternstewart.com/about_evalabout_eva_main.html>. Accessed November 1999.

Stern, J.M., G.B. Stewart, and D.H. Chew, 1995, The EVA Financial Management System, Journal of Applied Corporate Finance 8(2), Summer, 32-46.

Stewart, G.B., 1991, The Quest for Value, Harper: New York.

Stewart, G.B., 1994, EVA: Fact and Fantasy, Journal of Applied Corporate Finance 7(2), Summer, 71 84.

Uyemura, D.G., C.C. Kantor, and J.M. Petit, 1996, EVA for Banks: Value Creation, Risk Management, and Profitability Measurement, Journal of Applied Corporate Finance 9 (2), Summer, 94-111.

Van Staden, C.J., 1998, The Usefulness of Value Added Statement is South Africa, Managerial Finance 24 (11), 44-58.

Wallace, J.S., 1996, Adopting Residual Income-based Compensation Plans: Do You Get What You Paid For?, Journal of Accounting and Economics 24, 275-300.

Young, D., 1997, Economic Value-Added: A Primer for European Managers, European Management Journal 15(4), August, 335-343.

Young, S.D., 1999, Some Reflections on Accounting Adjustments and Economic Value-Added, Journal of Financial Statement Analysis 4 (2), Winter, 7-13.

Zimmerman, J.L., 1997, EVA and Divisional Performance Measurement: Capturing Synergies and Other Issues, Journal of Applied Corporate Finance 10 (2), Summer, 98-109. 